\title{
Implementasi Diversi Dalam Sistem Peradilan Pidana Anak Yang Berhadapan Dengan Hukum
}

\author{
Haris Dwi Saputro ${ }^{1}$ \\ Universitas Trunojoyo Madura \\ harissaputro74@gmail.com \\ Muhammad Miswarik ${ }^{2}$ \\ Universitas Trunojoyo Madura \\ muhammadmiswarik69@gmail.com
}

\begin{abstract}
ABSTRAK
Hukum pidana bersifat Ultimum Renedium yaitu sebagai upaya terakhir dalam penyelesaian sengketa pidana. Pengaturan alternaif penyelesaian sengketa dalam suatu aturan hukum sangatlah penting. Menangani anak yang melakukan tindak pidana, sudah seharusnya memperhatikan penanganan yang berbeda dengan orang dewasa, karena seringkali penanganan anak yang berkonflik dengan hukum disamakan dengan penganganan orang dewasa. Anak merupakan generasi penerus bangsa dan anak-anak pada umumnya masih memiliki sifat dasar yang labil sehingga kedudukannya masih membutuhkan perlindungan yang dapat dijadikan dasar untuk mencari solusi alternatif untuk menghindarkan anak dari suatu sistem peradilan pidana formal. Dalam menangani berbagai kenakalan anak yang melakukan tindak pidana, secara yuridis di Indonesia dapat ditandai dengan lahirnya Undang-Undang Nomor 11 Tahun 2012 tentang Sistem Perdadilan Pidana Anak, yang memberikan tujuan dalam menciptakan terobosan baru yang dapat menjadi solusi terbaik bagi anak yang melakukan tindak pidana. Lahirnya Undang-Undang tersebut dinilai lebih maju karena di dalam Undang-Undang Nomor 11 Tahun 2012 tentang Sistem Peradilan Anak yang baru ini mengutamakan pendekatan keadilan restroatif dengan melakukan upaya diversi dalam keseluruhan proses penyelesaian perkara tindak pidana anak. Diversi merupakan bentuk perlidungan bagi anak yang berkonflik dengan hukum.
\end{abstract}

Kata kunci: diversi; sistem perdilan pidana anak, anak yang berhadapan dengan hukum;

\begin{abstract}
Criminal law has the character of Ultimum Renedium, namely as the last remedy in solving criminal disputes. Thus the alternative arrangement of dispute resolution in a legal rule is very important. In dealing with children who commit criminal acts, it should be considered that the handling is different from adults, because often the handling of children in conflict with the law is the same as handling adults. Children are the nation's next generation and children generally still have an unstable nature so that their position still needs protection which can be used as a basis for finding alternative solutions to prevent children from a formal criminal justice system. In dealing with various delinquency of children who commit criminal acts, juridically in Indonesia it can be marked by the issuance of Law Number 11 of 2012 concerning the Juvenile Criminal Justice System, which aims to create a new breakthrough that can be the best solution for children who commit criminal acts. The birth of this law is considered to be more advanced because in the new Law Number 11 of 2012 concerning the Juvenile Justice System, it prioritizes a restrosive justice approach by making diversion efforts in the entire process of resolving cases of juvenile crime. With the existence of diversion it is expected as a form of protection for children in conflict with the law.
\end{abstract}

Key words: diversion; criminal criminal system for children, children in conflict with the law 


\section{PENDAHULUAN}

Konstitusi tertinggi yakni UUD NRI 1945 yang dimana sudah mengatur bahwasanya Indonesia adalah negara Hukum ${ }^{1}$. Kondisi bangsa Indonesia pada masa kini terhadap penanggulangan hukum dimasyarakat semakin hari justru makin mengalami kemunduran yang seharusnya bergerak ke arah perbaikan. Terdapat banyak kasus permasalahan penyelesaian anak yang berhadapan dengan hukum baik sebagai korban ataupun pelaku kejahatan. Banyaknya permasalahan tersebut pemerintah telah menyusun kebijakan sebagimana diatur di Undang-Undang Nomor 11 Tahun 2012 tentang Sistem Peradilan Pidana Anak. Salah satu yang perlu untuk diperhatikan dalam Undang-Undang Nomor 11 Tahun 2012 tantang Sistem Peradilan Pidana Anak ialah tentang pengalihan penyelesaian perkara anak dari proses peradilan ke proses diluar peradilan pidana atau bisa kita kenal dengan diversi. Diversi merupakan jalan alternatif dari sanksi pidana yang dapat mengurangi beberapa efek negatif dari keterlibatan anak dalam sistem peradilan.

Penerapan proses diversi ini dapat dikatakan juga berusaha untuk mengurangi kenakalan terhadap anak, residivisme dan meningkatkan keamanan publik terhadap anak terhadap kelangsungan hidup yang masih tumbuh berkembang, sehingga mengapa dalam diversi ini sangat menjunjung tinggi dari sistem Retorative Justice, dimana dalam sistem Restorative justice sistem peradilan pidana anak

1 Pasal 1 ayat (3) Undang-undang Dasar Negara Republik Indonesia 1945 merupakan bagian dari implementasi diversi. Dimana dalam suatu prinsip utama pelaksanaan konsep diversi ialah pendekatan persuasif atau pendekatan non penal agar memberikan kesempatan kepada seseorang untuk memperbaiki suatu kesalahan. ${ }^{2}$

Sehingga tidak jarang dalam hal ini diversi dikenal dengan upaya solutif diluar pengadilan, karena memang dalam hal diversi sangat mengedepankan kekeluargaan ketika dalam praktiknya. Model yang sangat ditonjolkan dalam bentuk penerapan pendekatan restorative justice terhadap diversi, pada dasarnya merupakan bentuk-bentuk yang menjadi variasi dari model dialog yang merupakan pelaksanaan dari bentuk musyawarah yang nantinya akan menghasikan mufakat. Dari nilai dasar inilah restorative justice sebagai implementasi dari nilai dasar yang ada dalam masyarakat Indonesia memiliki fondasi nilai yang kuat dalam membangun peradaban generasi penerus bangsa yang maju. 3

Berkembangnya zaman juga menjadi faktor terkait jumlah kenakalan anak semakin meningkat begitu pula tingkat keseriusanya kenakalan tersebut biasanya diawali dari tingkah laku menyimpang yang disebabkan oleh berbagai faktor internal dan eksternal. Perilaku menyimpang yang disebabkan faktor eksternal dapat dipengaruhi derasnya arus globalisasi

2 Randy Pradityo.2016. Garis Lurus Diversi Sebagai Pendekatan Non-Penal. Jurnal RechtsVinding Online .Jakarta. Hlm. 1

3 D.S. Dewi ,dkk. 2011. Mediasi Penal: Penerapan Restorative Justice Di Pengadilan Anak Indonesia. Bandung: Indi Publishing. hlm. 9 
dalam bidang teknologi, informasi komunikasi, dan kebutuhan ekonomi ternyata dapat menjadikan anak melakukan berbagai kejahatan tindak pidana. Sedangkan jika dipandang dari sudut pandang faktor internal yang menjadi sebab adalah kondisi kepribadian anak yang masih labil menjadi pangkal tingkah laku menyimpang. Dengan demikian, anak yang berhadapan dengan hukum perlu mendapatkan perlindungan khusus agar hak-hak anak tetap terpatuhi. Pada umumnya aspek perlindungan anak yang berhadapan dengan hukum lebih ditekankan pada hak-hak anak bukan pada kewajibana anak, karena anak secara umum belum dibebani kewajiban.

Tidak sedikit anak Indonesia diajukan ke pengadilan setiap tahunnya atas kejahatan ringan, seperti pencurian dan lain-lainnya. Tidak heran jika sembilan dari sepuluh anak yang melakukan tindak pidana dimasukan ke penjara atau rumah tahanan. Sudah seharusnya mereka mendapatkan dukungan, baik dari pengacara maupun dinas social untuk mendapatkan perlindungan. Kondisi saat ini sangat memprihatinkan karena banyak anak yang harus berhadapan dengan hukum dan mereka ditempatkan dipenahanan dan pemenjaraan bersama orang dewasa sehingga mereka rawan mengalami tindak kekerasan. Berbagai kasus tindak pidana yang melibatkan anak harus berhadapan dengan hukum merupakan masalah aktual dan faktual sebagai gejala sosial dan kriminal yang telah menimbulkan kekhawatiran dikalangan orang tua dan masyarakat pada

umumnya serta aparat penegak hukum. 4

Prinsip tentang perlindungan anak yaitu prinsip non diskriminasi yang mengutamakan kepentingan terbaik bagi anak dan hak untuk mendapatkan perlindungan hidup, kelangsungan hidup, tumbuh kembang anak termasuk terhadap anak yang melakukan tindak pidana atau anak yang berhadapan dengan hukum. Oleh karena itu jika terdapat anak yang berhadapan dengan hukum diperlukan suatu sistem peradilan pidana anak yang di dalamnya terdapat proses penyelesaian perkara anak di luar peradilan pidana. Seiring dengan lahirnya Undang-Undang Nomor 11 Tahun 2012 tentang Sistem Peradilan Pidana Anak munculah suatu gagasan terkait penyelesaian perkara anak yang berhadapan dengan hukum yaitu dengan cara pengalihan atau bisa kenal dengan proses diversi.

Secara teoritik, anak sebagai pelaku tindak pidana disebut dengan anak yang delikuen atau dalam hukum pidana dikatakan sebagai juvenile delinquency. Menurut Romli Atmasasmita dalam bukunya yang menyatakan bahwa juvenile delinquency adalah setiap perbuatan atau tingkah laku seorang anak di bawah umur 18 Tahun dan belum kawin yang merupakan pelanggaran terhadap norma-norma hukum yang berlaku serta dapat membahayakan perkembangan pribadi anak. 5 Yang dimana

\footnotetext{
4 Ulang Mangun Sosiawan, Prespektif Restoraktive Justice sebagai Wujud Perlindungan Anak yang Berhadapan dengan Hukum, Jurbal Penelitian Hukum DE JURE, Vol.16, No.14, hlm. 428

5 Romli Atmasasmita, Problema Kenakalan Anak-Anak Remaja (Bandung: Armico, 1983). Hlm. 40.
} 
dampak dari membahayakan perkembangan pribadi anak, tentu akan berpengaruh juga secara dominan dalam psikis dari seorang anak. Dengan adanya diversi, sedikit demi sedikit, pemulihan mental, psikis, dan fisik tentu akan nantinya juga akan lambat laun diobati, meskipun secara lambat laun diversi hanya memberi arti upaya luar peradilan, tetapi ketika sudah dilaksanakannya suatu diversi maka pemulihan pemulihan akibat traumatik dalam anak yang berhadapan dengan hukum ataupun anak yang melakukan tindak pidana juga akan langsung ditangani oleh lembaga lembaga terkait seperti pekerja anak, Komnas anak yang memang sudah berdasar pada ketentuan undang-undang yang berlaku.

Lembaga Pemasyarakatan pada umumnya bukanlah jalan untuk menyelesaikan permasalahan anak yang berhadapan dengan hukum melainkan justru dalam Lembaga Pemasyarakatan sering terjadi pelanggaran terhadap hak anak. Oleh karena itu anak seharusnya memiliki hak layak hidup sebagaimana dalam regulasi yang ada terhadap diberbagai fenomena yang menimpa anak yang telah berhadapan dengan hukum, penelitian ini dianggap penting untuk mengkaji bagaimana pelaksanaan penerapan diversi terhadap anak yang berhadapan dengan hukum.

Berdasarkan Uraian di atas, maka yang menjadi pokok permasalahan dalam penelitian ini adalah Bagaimanakah implementasi diversi dalam sistem peradilan anak yang berhadapan dengan hukum. Tujuan dilakukan penelitian ini adalah untuk menganalisis penerapan diversi terhadap anak yang berhadapan dengan hukum dlam sistem peradilan pidana anak.

\section{METODE PENELITIAN}

Penelitian ini menggunakan pendekatan hukum normatif. Dalam penelitian ini penulis menggunakan pendekatan hukum normatif dikarenakan dalam penelitian ini untuk mengkaji serta menelaah norma-norma hukum dalam Undang-Undang Nomor 11 Tahun 2012 tentang Sistem Peradilan Pidana Anak serta Peraturan Perundang-undangan yang berkaitan.

Jenis penelitian yang dilakukan ialah penelitian deskriptif yantu dengan menggambarkan penerapan diversi berdasarkan Undang-Undang Nomor 11 Tahun 2012 tentang Sistem Peradilan Pidana Anak dan Peraturan Perundang-undangan yang berkaitan khususnya yang terkait dengan anak yang berhadapan dengan hukum.

\section{HASIL DAN PEMBAHASAN}

\section{Sejarah Diversi}

Diversi merupakan kata dimana kata ini yang dikenal tidak asing dalam tatanan sistem peradilan anak di Indonesia. Namun siapa sangka, kata diversi ini masih terbilang muda yaitu muncul sejak lahirnya Undang-Undang Nomor 11 Tahun 2012 tentang Sistem Peradilan Pidana Anak atas dalih UndangUndang yang sebelumnya yang memang mengatur tentang peradilan anak dikenal yaitu Undang-Undang Nomor 3 Tahun 1997 tentang Peradilan Anak yang masih belum mengimplementasikan dari adanya peran diversi ini. Peradilan anak sebagaimana 
dimaksudkan adalah untuk melindungi dan mengayomi anak yang telah melakukan tindak pidana agar anak tersebut dapat menghadapi masa depannya yang bisa dikatakan panjang dan dapat memberi dirinya untuk kembali manusia yang mandiri, bertanggung jawab dan berguna bagi diri sendiri, orang tua atau keluarga, masyarakat disekitarnya, dan berbangsa maupun bernegara.

Berawal dari United Nations Standard Minimum Rules for the Administrator of Juvenile (The Beijing Rules) yang mencetuskan mengenai Diversi sebagai upaya mengatasi dampak negatif jika peradilan anak tetap ditegakkan, oleh karena itu para penegak hukum diberikan kewenangan untuk mengambil kebjiakan dalam menangani atau menyelesaikan masalah pelanggar anak agar tidak mengambil tindakan solutif formal ${ }^{6}$. Oleh karena itu tidak semata mata selalu apa yang menjadi peradilan pada umumya, mengingat daya psikis anak yang masih lemah dan juga kesempatan anak melanjutkan masa depannya yang masih terbilang panjang. Seperti yang tercantum dalam Rule 11.1, 11.2, dan 17.4 SMRIJ (The Beijing Rules) penyelesaian tanpa jalan fomal dalam artian menghentikan atau tidak meneruskan atau melepaskan dari proses pengadilan atau mengembalikan ataupun mengalihkan anak tersebut kepada masyarakat seutuhnya atau

\footnotetext{
6 R.Wiyono, Sistem peradilan pidana anak di Indonesia. Jakarta: Sinar Grafika,2019.hlm.46
}

bentuk pelayanan sosial lainnya yang dimana tindakan tersebut disebut diversion yang esensi utamanya adalah menghindari atau lebih mencegah dampak negatif dari proses pengadilan pada umumnya. Oleh karena itu sejak ide diversi dicanangkan PBB sebagai standard International pada tanggal 30 Oktober - 4 November 1994 di Viena, Australia, pada tahun 2000 lah menjadi awal penghimbauan atau seruan untuk mengimplementasikan upaya pengalihan perkara ini atau sering disebut diversi.

Indonesia yang menjadi awal diimplementasiknnya upaya diversi ini adalah ada pada Undang-Undang Nomor 11 Tahun 2012 tentang Sistem Peradilan Pidana Anak yang dimana ketentuan ketentuan tersebut diatur dalam Pasal 6-14 yang hingga kini menjadi acuan terhadap marwah peradilan anak di Indonesia sendiri.

\section{Pengertian Diversi}

Tentunya tidak asing jika mengenal kata diversi yang memang telah menjadi acuan atau pengalihan disetiap perkara anak dan memang dalam praktiknya diversi hanya siatur dalam ranah anak, tidak berdasar pada penyelesaian perkara pada umunya yaitu perkara orang dewasa. Undang-Undang Nomor 11 Tahun 2012 tentang Sistem Peradilan Pidana Anak telah mengaturnya secara konkrit mengenai diversi yang berarti "Pengalihan penyelesaian perkara anak dari proses peradilan pidana ke proses di luar peradilan pidana"' (Pasal 1 angka 7) dalam artian di luar sebagaima di maksud pada 
ketentuan tersebut artinya bahwa perkara masih bisa diselesaikan dengan cara semua pihak yang terlibat dalam suatu tindak pidana secara bersama-sama memecahkan dan menghasilkan kesepakatan yang memang anak tidak diharuskan untuk menempuh peradilan anak pada umumnya karena sebagai bentuk langkah preventif untuk menyelesaikan secara kekeluargaan.

Berbeda halnya ketika masih meninjau naskah akademik sebelum Undang-Undang Nomor 11 Tahun 2012 tentang Sistem Peradilan Pidana Anak disahkan. Menurut Nasir Djamli, yaitu yang ada pada Naskah akademik Rancangan Perundang-undangan tentang sistem peradilan anak tersebut yang memberikan artian diversi adalah suatu pengalihan penyelesaian kasus-kasus anak yang yang berhadapan dengan hukum dari proses pidana formal ke non formal yaitu penyelesaiannya secara damai antara pelaku atau tersangka atau terdakwa yang telah melakukan tindak pidana dengan korban tindak pidana yang difasilitasi oleh keluarga para pihak, masyarakat, pembimbing kemasyarakatan anak, pihak Kepolisian, pihak Kejaksaan, dan Hakim. ${ }^{7}$ Tentunya jika berdasar pada dua sumber maka dapat diartikan secara singkat mengenai diversi ini yaitu pengalihan perkara dari dalam ke luar perkara atau yang sering dikenal dalam dunia peradilan adalah Non litigasi.

7 M.Nasir Djamil, Anak bukan untuk Dihukum, Sinar Grafika,Jakarta,2013, Cetakan kedua. Hlm.137

\section{Tujuan Diversi}

Hal yang paling mendasar dari adanya implementasi diversi yaitu untuk menghindari dan menjauhkan anak dari proses peradilan, sehingga diharapkan sebagai langkah preventif bagi anak yang berhadapan dengan hukum agar kembali lagi ke dalam lingkungan masyarakat sosial secara harfiah. 8 Tetapi ketika melihat arah pandang ketentuan Undang-Undang khusus yang mengaturnya yaitu ada pada UndangUndang Nomor 11 Tahun 2012 tentang Sistem Peradialan Pidana Anak pada Pasal 6 , diversi bertujuan :

a. mencapai perdamaian antara korban dan Anak;

b. menyelesaikan perkara Anak di luar proses peradilan;

c. menghindarkan Anak dari perampasan kemerdekaan;

d. mendorong masyarakat untuk berpartisipasi; dan

e. menanamkan rasa tanggung jawab kepada Anak. 9

Oleh karena itu mengapa dalam hal ini aparatur penegak hukum harus melaksanakan ketentuan diversi sebagaimana yang termaksud pada Pasal 6, dikarenakan jika tidak sealur dengan apa yang sudah diatur, maka cita-cita diversi disini tidak akan terwujud yang dimana esensinya adalah mencari jalan damai.

\footnotetext{
8 R. Wiyono, loc.cit., hlm. 48

9 Pasal 6 Undang-Undang no. 11 tahun 2012 tentang Sistem peradilan anak
} 


\section{Penerapan Diversi dalam perkara anak}

Tidak semua problem anak yang berhadapan dengan hukum dapat diselesaikan dengan jalan diversi, karena jalan diversi ini juga menyangkut ketentuan ketentuan yang sudah diatur dalam ketentuan sistem peradilan anak itu sendiri. Meskipun pasal 7 ayat (1) UndangUndang Nomor 11 Tahun 2012 tentang Sistem Peradilan Pidana

Anak yang menyatakan wajib diupayakan diversi pada tingkat 3P (penyidikan, penuntutan, pemeriksaan sidang) namun ayat (2) nya juga melanjutkan apa maksud dari wajib dilakukan diversi ini yaitu wajib jika tindak pidana anak yang dilakukan dibawah tujuh tahun penjara, dan juga bukan merupakan pengulangan tindak pidana. Artinya disini adalah koridor dari adanya implementasi diversi harus tetap berpegang teguh pada pasal 7 ayat (2). Tetapi dalam hal pasal 7 ayat (2) hanya bersifat imperatif atau fakultatif atau kondisional, bisa saja hal prasyarat tersebut yang menjadi batasan dapat saja diupayakan diversi. Dalam praktiknya diversi hanya dapat dilakukan pada pengadilan negeri atau pada tingkat pertama, karena memang sesuai yang termaksud pada Pasal 6 KUHAP diversi termasuk ke dalam acara pemeriksaan Tindak pidana ringan. Sebenarnya dalam Undang-Undang Nomor 11 Tahun 2012 tentang Sistem Peradilan Pidana Anak, dilanjutkannya perkara ke pengadilan tinggi ini sifatnya devolutif yang berarti seluruh pemeriksaan perkara dipindahkan dan diulang oleh Pengadilan Tinggi. Dalam praktiknya diversi dilakukan selayaknya musyawarah tetapi melibatkan beberapa pihak antara korban maupun tersangka.
Musyawarah adalah pembahasan bersama dengan maksud mencapai keputusan atas penyelesian masalah. ${ }^{10}$ Seperti yang termaktub dalam pasal 8 ayat (1) Undang-Undang Nomor 11 Tahun 2012 tentang Sistem Peradilan Pidana Anak, bahwasanya :

" Proses diversi dilakukan melalui musyawarah dengan melibatkan anak dan orang tua atau walinya,korban dan/atau orang tua atau walinya,pembimbing kemasyarakatan ,serta pekerja sosial profesional berdasarkan pendekatan keadilan restoratif."

Artinya dalam hal ini implementasi diversi ketika anak berhadapan dengan hukum dapat dilakukan metode selayaknya musyawarah atau melalui pembahasan bersama dengan maksud mencapai keputusan mengenai diversi yang akan diterapkan dalam penyelesaian perkara anak. Tetapi dalam hal ini, dalam metode musyawarah haruslah memperhatikan hal-hal yang harus diterangkan dalam suatu penerapan diversi dilakukan, seperti yang tertera pada pasal 8 ayat (3) Undang-Undang Nomor 11 Tahun 2012 tentang Sistem Peradilan Pidana Anak menyatakan bahwasanya diversi harus wajib memperhatikan ;

a. Kepentingan Korban

b. Kesejahteraan dan tanggung jawab anak

c. Penghindaran stigma negatif

d. Penghindaran pembalasan

e. Keharmonisan Masyarakat

10 Pusat Bahasa Departemen Pendidikan Nasional, Kamus Besar Bahasa Indonesia, Balai Pustaka, Jakarta,2003, Cetakan Ketiga, hlm. 768 


\section{f. Kepatutan, kesulitan, dan ketertiban uтит.}

Sangat penting sekali keenam hal pokok yang harus dilakukan sebelum dilakukan diversi atau musyawarah, karena anak disini bukan sama seperti layaknya orang dewasa, yang mampu menganalisa tindakan sebelum berfikir, tetapi memang sifat anak yang cenderung labil bisa melakukan hal-hal yang bisa dikatakan diluar nalar, seperti pembunuhan, penganiayaan, dll. oleh karena itu mengapa peran pihak yang melakukan musyawarah sangat penting sekali seperti yang sudah diatur dalam Pasal 8 ayat (2) termasuk anak dan orang tua/wali dari anak, korban dan/atau orang tua atau wali dari korban, pembimbing kemasyarakatan, serta pekerja sosial profesional harus bisa berkorelasi dan menjadi solusi bagi kedua belah pihak yang bersangkutan.

Tidak hanya pihak pihak yang melakukan musyawarah diharuskan mempertimbangkan seperti yang termatum dalam pasal 8 ayat (3) tetapi dengan adanya Pasal 9 ayat (1) UndangUndang Nomor 11 Tahun 2012 tentang Sistem Peradila Pidana Anak para pihak lainnya seperti penyidik, penuntut umum, maupun hakim juga harus mempertimbangkan jika langkah diversi dilakukan, diantaranya sebagai berikut

a. Kategori Tindak Pidana yang dilakukan oleh anak yang berhadapan dengan hukum, tentunya pihak yang menangani musyawarah dalam diversi harus lebih menimbang sebelum memutus perkara, karena pada praktiknya peradailan anak sangat jauh berbeda pada peradilan yang umumnya orang dewasa dilakukan. Ancaman pidana semakin rendah, langkah diversi pun dangat diprioritaskan untuk dipraktikkan, begitupun sebaliknya. Oleh karena itu mengapa dalam kategori penanganan diversi sangat diprioritaskan bagi ancaman pidana dibawah 7 tahun penjara, karena secara nalar, jika diancam pidana penjara lebih dari tujuh tahun atau 7 tahun keatas pasti dalam hal ini cenderung bisa dikategorikan dalam tindak pidana serius, seperti pemerkosaan, pembunuhan, peredaran narkotika, terorisme, dan sebagainya.

b. Umur, umur juga menjadi alasan mengapa dalam hal ini harus dipertimbangkan lebih lanjut, dikarenakan semakin tinggi umur anak tersebut, daya berpikir atau psikisnya juga semakin progresif akan suatu hal. Oleh karena itu mengapa Pasal 9 ayat (1) ini lebih memprioritaskan upaya diversi pada umur yang lebih muda atau cenderung masih rendah.

c. Hasil Penelitian dari BAPAS (Balai Pemasyarakatan), sangat penting sekali dalam hal ini mengapa penelitian dari BAPAS juga menjadi bahan lirikan atau pandangan dari penyidik, penuntut umum, maupun hakim. Dikarenakan penelitaian kemasyarakatan berhak dilakukan oleh BAPAS itu sendiri, entah identitas, motif pelaku maupun korban dan sebagainya yang berhubungan dengan anak berhadapan dengan hukum yang bersangkutan.

d. Dukungan keluarga dan Masyarakat, hal ini juga menjadi penting dikarenakan pendekatan sosial maupun interaksi sosial anak yang berhadapan dengan hukum tersebut ada pada keluarga dan orang terdekat sehingga 
mengapa dalam hal ini musyawarah harus memperhatikan data data dari keluarga dan orang terdekat demi kepentingan diversi yang dilakukan. 11

Dari hal-hal yang harus dipertimbangkan tersebut, piihak pihak yang melakukan musyawarah atau menerapkan diversi bisa memperoleh kesepakatan diversi/ Tetapi dalam hal ini untuk memperoleh kesepakatan hasil diversi, sangat diperlukan dengan adanya persetujuan korban dan/atau keluarga anak korban serta kesediaan anak korban dan keluarganya seperti yang termaksud dalam ketentuan Pasal 9 ayat (2) kecuali untuk tindakan sebagai berikut ;

a. Tindakan pidana yang berupa pelanggaran, dalam hal pelanggaran memang ada pengecualian dikarenakan menurut Moeljatno, pelanggaran adalah perguatan yang melawan hukum yang hanya dapat ditentukan setelah ada hukum atau UndangUndang khusus yang mengaturnya. Artinya dalam hal ini ketika pelanggaran ini bisa dikatakan bersifat fakultatif/imperatif karena selama peraturan khusus mengatur mengenai pelanggaran yang dilakukan dapat dibawa ke ranah pidana tetapi jika tidak sebaliknya.

b. Tindak pidana ringan, tindak pidana ringan sering dikenal dengan tipiring dalam penamaan hukum, tindak pidana ringan adalah tindak pidana yang diancam dengan pidana penjara atau pidana kurungan paling lama 3 bulan.

11 R. Wiyono, loc.cit., hlm. 54 c. Tindak Pidana tanpa korban

d. Nilai kerugian korban tidak lebih dari nilai upah minimum provinsi setempat

Ketentuan tersebut juga disebutkan bahwa kesepakatan diversi harus mendapatkan persetujuan dari korban tindak pidana dan/atau keluarga korban serta kesediaan anak dan keluarganya. Tetapi dalam hal ini apakah penting mendapatkan persetujuan dan kesediaan demi kesepakatan diversi, hal ini sebenarnya relatif, karena tidak harus mendapatkan persetujuan korban dan/atau keluarga anak korban serta kesediaan anak dan keluarganya. Ketika melihat Pasal 10 ayat (1) Undang-Undang Nomor 11 Tahun 2012 tentang Sistem Peradilan Pidana Anak menentukan bahwasanya penyidik bersama pelaku dan/atau keluarganya, pembimbing kemasyarakatan, serta melibatkan tokoh masyarakat seperti ulama, guru, dsb bisa melakukan kesepakatan diversi.

Penyidik atas arahan atau rekomendasi dari pembimbing kemasyarakatan seperti yang termakstub dalam pasal 10 ayat (2) UndangUndang Nomor 11 Tahun 2012 tentang Sistem Peradilan Pidana Anak dapat berbentuk sebagai berikut :

a. Pengembalian kerugian dalam hal ada korban, yang berarti entah kerugian secara materiil maupun immateriil harus dipenuhi dalam kesepakatan diversi yang dilakukan oleh pelaku terhadap anak korban, dikarenakan ini sangat penting jika sewaktu waktu dalam musyawarah diversi menggunakan opsi ganti rugi atas dasar pemenuhan kesepakatan yang dilakukan.

Universitas Trunojoyo Madura 
b. Rehabilitasi medis dan psikososial, rehabilitasi dalam artian diperbaiki,dikumpulkan setelah itu dikembalikanlah ke masyarakat sosial seutuhnya, tetapi dalam hal ini medis dalam artian ditangani dengan media kesehatan entah rumah sakit, psikiater, maupun psikolog yang bertujuan mengembalikan psikis pada anak korban maupun pelaku.

c. Penyerahan kembali kepada orang tua atau wali, dalam hal ini bisa dikatakan harus dan perlu bimbingan seutuhnya oleh peran kedua orang tua/wali, dikarenaan pendekatan sosial maupun interaksi sosial pertama dibangun oleh keluarga terdekat.

d. Keikutsertaan dalam pendidikan atau pelatihan di lembaga pendidikan atau LPKS paling lama 3 bulan yang dimana lembaga ini memang bertindak sebagai penyelenggara kesejahteraan sosial dan waktu 3 bulan merupakan waktu yang bisa dkatakan proporsional jika kesepakan dalam diversi itu memberikan prasyarat mengenai pendidikan dan pelayihan ini.

e. Pelayanan masyarakat paling lama 3 bulan, dalam hal ini pun peran dan tanggung jawab pembimbing kemasyarakatan sangat diperlukan, karena semua perkara dalam peradilan anak anak yang berhadapan dalam hukum maupun anak yang diakatakan anak korban pasti akan meminta laporan mengenai laporan penelitian kemasyarakatan yang dimana penelitian tersebut juga termasuk ke dalam ranah pelayanan masyarakat.

Ketentuan diatas lahirlah hasil kesepakatan diversi, dimana dalam hal ini hasil hasil tersebut memang sudah dilalui berbagai metode dalam diversi sehingga Pasal 11 Undang-Undang Nomor 11 Tahun 2012 tentang Sistem Peradilan Pidana Anak menentukan kesepakatan hasil diversi itu sendiri, yang dimana berbentuk antara lain :

a. Perdamaian dengan atau tanpa ganti kerugian, artinya dalam hal ini tidak ada batasan maupun jaminan ketika kesepakatan tersebut sudah disetujui oleh kedua belah pihak, dikarenakan sifat damai adalah jalan yang utama dalam ketentuan ini.

b. Penyerahan kembali kepada orang tua/wali, artinya jika sudah dikatakan sepakat berdamai bisa saja langung dikembalikan ke pengampuan orang tua/wali nya lagi dalam hal masih tahap pembimbingan yang dilakukan oleh orang tua/wali tersebut.

c. Keikutsertaan dalam pendidikan atau pelatihan di lembaga pendidikan atau LPKS paling lama 3 bulan

d. Pelayanan Masyarakat

Ketentuan Pasal 11 ini sifatnya imperatif atau fakultatif karena memang menunjukkan tidak harus berpatokan hasil kesepakatan diversi pada aturan yang telah ditentukan, kata frasa "antara lain" juga menunjukkan adanya hal yang sangat jabar atau jamak dalam penguaraiannya. Sehinga mengapa dalam hal Pasal 12 ayat (1) menunjukkan bahwasanya harus dibentuk kesepakatan diversi tetapi dalam hal ini harus memang berperan aktif dari pihak yang terlibat untuk memenuhi dari hasil kesepakatan itu, seperti Kepolisian, Kejaksaan maupun 
Pengadilan yang memang merupakan instansi/lembaga subsistem peradilan pidana yang berhak mengajukan diversi. Tetapi dalam hal ini harus memperhatikan tenggang waktu dalam membentuk kesepakatan diversi seperti yang diatur dalam Pasal 12 ayat (2) dimana di setiap tingkat pemeriksaan ke pengadilan negeri sesuai dengan daerah hukumnya yaitu harus dalam waktu paling lama 3 (tiga) hari sejak kesepakatan dicapai untuk memperoleh penetapan.

Oleh karena itu ketiga lembaga ini sangat berperan aktif untuk membentuk suatu kesepakatan diversi karena disetiap tahapan acara entah kepolisian, kejaksaan, maupun pengadilan akan mengupayakan diversi sebagaimana mungkin masih berlaku dan memenuhi pada Pasal 7 ayat (2) Undang-Undang Nomor 11 Tahun 2012 tentang Sistem Peradilan Pidana Anak.

Setelah sudah ditetapkan diversi itu, dari perkara anak yang berhadapan dengan hukum tersebut, barulah Ketua pengadilan akan mengeluarkan penetapan tersebut maksimal 3 hari sejak kesepakatan itu disetujui oleh semua pihak dan akan disampaikan kepada pembimbing kemasyarakatan, Penyidik, Penuntut Umum, dan Hakim yang menangani perkara anak tersebut seperti yang termaksud dalam Pasal 12 ayat (3) Undang-Undang Nomor 11 Tahun 2012 tentang Sistem Peradilan Pidana Anak. Selanjutnya disemua lembaga instansi subsistem peradilan pidana akan menerapkan penerbitan penghentian diversi karena dalam hal ini hakim sudah menganggap final atau sudah akhir diversi jika penetapan diversi sudah diterbitkan dan menghentikan pemeriksaan perkara anak didepan sidang Pengadilan. Oleh karena itu mengapa Pasal 13 Undang-Undang Nomor 11 Tahun 2012 tentang Sistem Peradilan Pidana Anak menjelaskan mengenai adanya kecenderungan keberlanjutan diversi jika :

a. Proses diversi tidak menghasilkan kesepakatan

Artinya dalam hal ini diversi yang dilakukan tidak sampai menghasilkan kesepakatan, maka sebagai bukti pertanggungjawaban para pihak yang terlibat juga akan melanjutkan kembali dari perkara yang bersangkutan, karena dalam hal tidak terpenuhinya kesepakatan divesri itu sendiri yang menyebabkan tidak adanya suatu penetapan.

b. Kesepakatan diversi tidak dilaksanakan

Artinya ada kecenderungan pihak pihak yang terlibat tidak melanjutkan proses diversi meskipun telah mencapai hasil kesepakatan, sehingga adanya kecenderungan untuk keberlanjutan proses diversi kembali. 12

Ketentuan diatas cenderung kepada pelaksanaan diversi yang dilakukan, namun dalam hal ini harus kita ketahui mengenai subyek yang melaksanakan kesepakatan diversi entah pengawsan dan lain lain sebenarnya sudah ternaktub dalam pasal 14 ayat (1) dimana berbunyi:

“ Pengawasan atas proses Diversi dan pelaksanaan kesepakatan yang dihasilkan berada pada atasan langsung pejabat yang bertanggung jawab di setiap tingkat

12 Lihat penjelasan Pasal 13 UNDANG-UNDANG No. 11 tahun 2012 
pemeriksaan “

Dari ketentuan pasal diatas dapat diketahui bahwa dalam pelaksanaan kesepakatan diversi, pada setiap lembaga entah kepolisian, kejaksaan, maupun pengadilan juga turut mengawasi mengenai kesepakatan diversi yang dilakukan. Seperti pembimbing kemasyarakatan yang wajib melakukan pendampingan dan pengawasan. Seperti yang diatur pada Pasal 14 ayat (2). Tetapi dalam hal jika kesepakatan diversi tidak dilaksanakan dalam waktu yang ditentukan maka Pasal 14 ayat (3) UndangUndang Nomor 11 Tahun 2012 tentang Sistem Peradilan Pidana Anak yang memang mengatur bahwasanya diharuskan dari Pembimbing Kemasyarakatan segera membuat laporan kepada Penyidik, Penuntut Umum, dan Hakim bahwa kesepakatan diversi tidak dilaksanakan. Oleh karena itu mengapa dalam hal sebagai tindak lanjut, Penyidik, Penuntut Umum dan Hakim akan mencabut atau menyatakan tidak berlaku lagi penetapan penghentian penyidikan, penetapan penghentian penuntutan, dan penetapan penghentian pemeriksaan yang telah dikeluarkan yang dimana proses peradilan anak diteruskan.

\section{KESIMPULAN}

Dari penjabaran yang telah dibahas diatas maka dapat diperoleh suatu kesimpulan pentingnya terhadap pererapan diversi bagi anak yang berhadapan dengan hukum dalam sistem peradilan pidana yang mana sebagai alternatif penyelesaian perkara tindak pidana yang dilakukan oleh anak. Diversi dalam sistem peradilan pidana anak merupakan implementasi sistem restroative justice untuk memberikan perlindungan dan keadilan bagi anak yang telah melakukan tindak pidana. Pelaksanaan diversi yang terkandung di dalam sistem peradilan pidan anak adalah pengalihan penyelesaian perkara anak dari proses peradilan pidana ke proses diluar peradilan pidana dengan cara nonformal dengan menekankan pada pemulihan kembali pada keadaan semula dan bukan bersifat pembalasan. Dalam proses diversi itu sendiri tentu juga ada pihak yang dilibatkan yakni anak, orang tua, korban, dan atau orang tua/wali, pembimbing kemasyarakatan dan pekerja sosial profesional dengan berdasarkan pendekatan keadilan restorative justice. Tetapi ketika berbicara terkait pelaksanaan diversi tentu semua organ penegak hukum selalu melakukan pengupayaan dan pelaksanan terkait diversi termasuk dalam pihak kepolisian dalam penyelidikan dan penyidikan ,kejaksaan dalam proses penuntutan, dan Hakim dalam Persidangan seperti yang termaktub dalam pasal 7 ayat (1) UU no. 11 tahun 2012 tentang Sistem Peradilan Pidana anak. Tetapi dalam hal ini masing masing pengupayaan diversi dalam proses penegakan hukum memiliki rentang waktu yang relatif sama, seperti dalam pasal 29 ayat (1) dan (2) UU no. 11 tahun 2012 tentang Sistem Peradilan Pidana anak yang dimana dalam penyidikan pihak kepolisian sebelumnya meminta persetujuan antara pihak pelaku dan korban agar diupayakan diversi, dan diberikan rentang waktu 7 hari setelah laporan tersebut diterima oleh kepolisian setelah disetujui baru 30 
hari tersebut masa dari persetujuan terhitung atas dasar pelaksanaan diversi. Sama hal nya dengan proses penuntutan seperti yang termaktub dalam pasal 42 ayat (1) dan (2) UU no. 11 tahun 2012 tentang Sistem Peradilan Pidana anak, dalam hal ini penuntut umum wajib mengupayakan diversi terhadap pelaku dan korban selama 7 hari setelah menerima berkas perkara dari penyidik, dan jika selesai mengupayakan dan kedua belah pihak setuju dengan diversi maka 30 hari juga berlaku atas dasar pelaksanaan diversi sejak penuntut umum menerima persetujuan tersebut. Dan juga berlaku bagi seorang Hakim dalam persidangan seperti yang etrmaktub dalam pasal 52 ayat (2) dan (3) UU no. 11 tahun 2012 tentang Sistem Peradilan Pidana anak dimana hakim wajib mengupayakan diversi terhadap pelaku dan korban selama 7 hari setelah menerima berkas perkara dari penuntut umum, dan jika selesai mengupayakan dan kedua belah pihak setuju dengan diversi maka 30 hari juga berlaku atas dasar pelaksanaan diversi sejak penuntut umum menerima persetujuan tersebut.

Oleh karena itu kepada aparat penegak hukum terkhususnya dalam melaksanakan Penyidikan, Penuntutan, Pemeriksaan sidang di Pengadilan hendaknya mengutamakan proses pelaksanaan diversi sebagai salah satu alternatif dalam menangani anak yang berhadapan dengan hukum. Dalam hal ini aparat berwenang pun sudah seharusnya mempunyai kemauan dan kemampuan yang kuat untuk menangani perkara yang melibatkan anak sesuai dengan prinsip the best interest of the children atau mengutamakan kepentingan terbaik bagi anak, karena anak selain menjadi generasi penerus bangsa dan juga nantinya akan menjadi penyokong masa depan. Dengan demikian restorative justice benar-benar terlaksana demi kepentingan terbaik bagi anak dimasa sekarang maupun masa yang akan datang 13 . Karena dalam hal ini diversi bukan hanya menuntaskan paham prinsip pembalasan tetapi rasa sadar dan kekeluargaan menjadi prioritas utama, meskipun cakupan dari diversi ini hanya bisa merangkul perbuatan perbuatan khusus yang kadarnya sendiri tidak begitu

\section{DAFTAR RUJUKAN}

D.S. Dewi ,dkk. 2011. Mediasi Penal: Penerapan Restorative Justice Di Pengadilan Anak Indonesia. Bandung: Indi Publishing.

Djamil, M. Nasir, 2013, 'Anak bukan untuk Dihukum', Jakarta: Sinar Grafika, Cetakan kedua.

Pusat Bahasa Departemen Pendidikan Nasional, 2003, 'Kamus Besar Bahasa Indonesia', Jakarta: Balai Pustaka, Cetakan Ketiga.

Pradityo, Randy ,2016. Restorative Justice Dalam Sistem Peradilan Anak, Jurnal Hukum dan Peradilan, Volume 5 Nomor 3. hlm. 329.

Pradityo, Randy .2016. Garis Lurus Diversi Sebagai Pendekatan Non-Penal. Jurnal RechtsVinding Online .Jakarta. Hlm. 1

Atmasasmita, Romli, Problema Kenakalan Anak-Anak Remaja (Bandung: Armico, 1983). Hlm. 40

13 Randy Pradityo,2016. Restorative Justice Dalam Sistem Peradilan Anak, Jurnal Hukum dan Peradilan, Volume 5 Nomor 3. hlm. 329 
Sosiawan Ulang Mangun, 'Prespektif Restoraktive Justice sebagai Wujud Perlindungan Anak yang Berhadapan dengan Hukum', Jurbal Penelitian Hukum DE JURE, Vol.16, No.14.

Undang-Undang Dasar Negara Republik Indonesia 1945

Undang-Undang Nomor 11 Tahun 2012 tentang Sistem Peradilan Pidana Anak.

Wiyono, R., 2019, 'Sistem peradilan pidana anak di Indonesia', Jakarta: Sinar Grafika. 
